\title{
ТЕЛОТО И ГРАНИЦИТЕ НА ТЕЛЕСНОСТА ВО „СТАКЛЕНАТА ГРАНИЦА“НА КАРЛОС ФУЕНТЕС
}

Сања Михајловиќ-Костадиновска

Универзитет „Св. Кирил и Методиј“, Скопје

sanja.flf@gmail.com

„Стаклената граница“, полифоничниот роман на Карлос Фуентес, обработува голем број теми како миграциите, класните разлики, ксенофобијата, корупцијата и деконструира серија лингвистички, социјални, културни и симболички граници, притоа преиспитувајќи ги и самите граници меѓу жанровите. Во овој труд ја продлабочуваме анализата на делото од перспективата на телесноста и телото како појдовна точка од којашто се повлекуваат многу граници: оние што ги наметнува модата, полот, сексуалната определба, оние што произлегуваат од односите на моќ или од привидната слобода на женското тело, оние што стојат меѓу нас и нашето минато, меѓу животот и смртта.

Клучни зборови: тело, граничност, „Стаклена граница“, Карлос Фуентес 


\title{
THE BODY AND THE LIMITS OF CORPOREALITY IN THE CRYSTAL FRONTIER BY CARLOS FUENTES
}

\author{
Sanja Mihajlovik-Kostadinovska \\ Ss Cyril and Methodius University, Skopje \\ sanja.flf@gmail.com
}

The Crystal Frontier, a polyphonic novel by Carlos Fuentes, deals with a number of themes such as migration, class differences, xenophobia, corruption and deconstructs a lot of linguistic, social, cultural, symbolic boundaries, re-examining furthermore the boundaries between genres. In this paper, we further analyze the work from the perspective of the corporeality and the body that represents a starting point from which many borders are delineated: those imposed by fashion, gender, sexual orientation, those derived from the power relations or the apparent freedom of the female body, those who stand between us and our past, between life and death.

Key words: body, liminality, The Crystal Frontier, Carlos Fuentes 
Порозни се човековите граници, над кои облаците неказнето пловат, велеше полската поетеса Вислава Шимборска, добитничка на Нобеловата награда за книжевност. За апсурдноста на границите, но и за потребата да се омеѓуваме, зборува и несудениот добитник на ова престижно признание, мексиканскиот писател Карлос Фуентес, во неговото жанровски нетипично дело „Стаклената граница“ (La frontera de cristal). Имено, главниот протагонист во овој фрагментарен роман или, ако се претпочита, збирка од девет раскази со заедничка тематска нишка, би можело да се каже дека е токму границата меѓу Мексико и Соединетите Американски Држави - место каде што се судираат две култури, два јазика, две различни општественоекономски уредувања, но и каде што се раѓаат нови хибридни идентитетски форми преку кои се поместуваат многу симболични граници. Како и многу други граници низ светот, и оваа останува да биде „отворена рана“ (Anzaldúa 1987: 3) којашто засега милиони луѓе што секојдневно се жртви на ксенофобија, корупција, трговија со луѓе и којашто, иронично, колку повеќе се инсистира физички да се зацврсти и заsида, толку повеќе ја истакнува својата амбивалентност. Сепак, во овој труд нема да се занимаваме со темите на миграцијата или со честите слики за Мексиканецот во делата на Фуентес како производ на автоперцепциите во споредба со неговиот американски „гротескно нееднаков близнак“ (Boldy 2016: 83, преводот е на авторката), туку ќе се задржиме на еден аспект во ова дело што, според наши сознанија, е малку или недоволно проучуван, а тоа се границите на телесното и телесноста како граница. Односно, ќе се обидеме да покажеме дека телото како топос (Симова 2012: 130) е првичната и единствената граница меѓу јаството и другоста, своевидна стаклена граница којашто ни овозможува да се видиме себеси како блед одраз, но да ги видиме и другите во нас, некаде отаде границата. Поточно, ќе се осврнеме на деловите во книгата што се однесуваат на директен или на индиректен опис на телата на протагонистите, на латентната потреба постојано да го потврдуваат своето присуство преку телесноста, да се соголуваат во потрага по својата сушност или да се отелотворуваат преку контактот со другите.

„Стаклената граница“, како што спомнавме, се состои од девет дела, коишто може да се читаат независно еден од друг, но и како парчиња од еден мозаик од случки и од ликови што ги обединува не само заедничкиот хронотоп - САД и Мексико во ерата по северноамериканскиот договор за слободна трговија - туку и еден лик: валканиот, корумпиран, бескрупулозен бизнисмен Леонардо Баросо. ${ }^{1}$ Првиот расказ/поглавје зборува за Мичелина Лаборде, припадничка на високата класа и штитеничка на Леонардо Баросо, којашто доаѓа во Кампасас за да се омажи со синот на Леонардо за набргу

\footnotetext{
1 Ликот на Леонардо Баросо во „Стаклената граница“ сепак не е централен лик, но е сеприсутен преку односите со другите ликови.
} 
потоа да му стане љубовница токму на Леонардо. Во второто поглавје, главен протагонист е Хуан Самора којшто благодарение на финансиската помош од Леонардо Баросо заминува на школување во САД каде што ја открива својата хомосексуалност, но поради којашто е отфрлен и принуден да се врати во Мексико. Третиот расказ е еден вид онирична и фантазмагорична рекреација на дикенсовата „Божиќна приказна“, во којашто главниот лик, Дионисио Ранхел, престижен готвач и гастроном во САД, вечера со неколку жени коишто се појавуваат и исчезнуваат, по што тој ќе доживее еден вид откровение и ќе се врати во Мексико, оставајќи го зад себе лажниот живот на успешен човек ${ }^{2}$. Четвртиот расказ е единствениот расказ со наратор во прво лице, каде што парализираниот и финансиски пропаднат брат на Леонардо Баросо, Емилијано Баросо, го реконструира сопственото јас преку спомените за себе и за неговите блиски од коишто се чувствува отфрлен. Петтиот расказ зборува за работничките во текстилните фабрики на границата меѓу САД и Мексико, таканаречени „макиладорас“, што се во сопственост на Леонардо Баросо. Овој расказ зборува за неостварените соништа на жените од работничката класа, за нивната привидна независност и за жртвите што треба да му ги принесат на империјалистичкиот бог. Дејството во шестиот расказ е сместено во Чикаго, каде што повторно се вкрстуваат два различни света, оној на богатата, намќореста вдовица Мис Ејми и оној на мексиканската куќна помошничка Хосефина. Два света кои отпрвин се разидуваат, а потоа успеваат да најдат заеднички јазик во самотијата што ја споделуваат. Седмиот расказ е расказот по којшто е именувана целата збирка/роман и во него протагонисти се мексиканскиот наемен работник којшто преку фирмата на Леонардо Баросо оди во САД за да работи како чистач на прозорците на облакодерите и каде што има прилика да се запознае со Одри, Американка што работи во една од канцелариите, но нивната средба е единствено можна без физички контакт, само преку стаклената граница на прозорците. Осмиот расказ е една фатална љубовна приказна меѓу Мексиканецот Леандро и Шпанката Енкарнасион, коишто загинуваат во сообраќајна несреќа додека Леандро е во служба на Леонардо Баросо како негов личен шофер. И последниот, деветти расказ, е еден вид обединувачки расказ во којшто повторно се појавуваат дел од ликовите од претходните раскази, се расветлуваат или продолжуваат нечии приказни и каде што се дознава за смртта на Леонардо Баросо.

Целиот текст на Фуентес може да се разгледува низ призмата на границата како простор којшто го детерминира однесувањето на ликовите, принудени постојано да се бараат себеси на спротивната страна од онаа каде што се. ${ }^{3}$

\footnotetext{
2 Овој, како и шестиот расказ, се единствените раскази во коишто се губи врската со обединувачкиот лик Леонардо Баросо.

${ }^{3}$ Оваа невидлива граница меѓу двете земји може да се разгледува како еден вид хетеротропија, според терминологијата на Фуко (Foucault 1984), односно како огледало што истовремено е место каде што се гледаме себеси, но и од каде што сме отсутни.
} 
Оттука и поаѓа нашата анализа, односно од „телесното“ што „секогаш е“ (Мухиќ 1994: 14), односно се манифестира во просторот како „стремеж кон обликот“ (Мухиќ 1994: 15), она „парче простор“ (Augé 1992: 66) коешто го „имплицира““ (Tuan 1979: 389) остатокот од просторот, односно преку своите сетила, својата вертикалност и преку својот говор го организира светот околу себе (Tuan 1979). Но, телото не е само една просторна инстанца, единствената преку којашто ја чувствуваме, доживуваме и живееме реалноста (Paredes Ortiz 2003) туку како и кој било друг простор на којшто се испишува личната и колективната меморија, со текот на времето и тоа станува текст, конструкт на географските, општествените, политичките, културните прилики. Од различните перцепции за телото низ историјата, меѓу кои долго време доминирале дуалистичките претстави за телото во спрега со духот или умот, наследени најпрво од Платон, а потоа и од Декарт, би рекле дека во делото што е предмет на наша анализа, сосема изостанува ваквата дихотомија, но не поради некаква претензија таа да се помири во некаков монизам, каков што предлагал Спиноза ${ }^{4}$ туку повеќе преку изоставање на духовната димензија на телото и неговото поимање, пред сѐ, во материјална смисла, односно како „инструмент, алат, или машина што ѝ стои на располагање на свеста““ (Грос 2003: 32). ${ }^{5}$ Аспектите на телесноста за кои ќе зборуваме во овој труд ќе произлегуваат од овие неколку набројани концепти, односно просторноста на телото и можноста јасно да се постават границите помеѓу она што е тело и што не е тело, и она што е тело и друго тело, а телесноста којашто се промислува себеси, којашто се чита и (само)толкува како текст или којашто се објективизира како инструмент за полесна манипулација, ќе биде разгледувана низ следниве релации: телото и моќта, телото и слободата, обезличеното тело, бестелесното тело, телата без контакт, телото и самотијата и телото и смртта

Ќе започнеме најпрво со односот помеѓу телата и моќта. Ограничениот простор на овој труд не ни дозволува да дадеме подетален преглед на различните начини на коишто економската и идеолошката моќ влијаат, го обликуваат и го создаваат дискурсот на телото (Foucault 1998), па затоа ќe ce задржиме на оној аспект што францускиот филозоф го истакнува, а тоа е потчинетоста на телата, којашто може да биде систематска, организирана, но и суптилна, и којашто има за цел да направи послушни, корисни, функционални тела (Фуко 2004: 30). Во делото на Фуентес, во неколку раскази очигледно е чувството на нелагодност на телата поради облеката што ја носат, којашто неретко на ликовите им ја наметнуваат модните трендови

\footnotetext{
4 За подетални информации околу претставите за телото, пред сѐ преку неговата филозофска димензија, упатуваме на магистерскиот трудот на Гоце Смилевски, „Телото во романите на Милан Кундера“, објавен во 2005 година.

5 Оваа перцепција на телото Грос ја наведува како една од трите кои произлегле од картезијанизмот, покрај телото сфатено како објект на непомирливите природни и хуманистички науки, или како „означувачки медиум, како средство за изразување“ (Грос 2003: $33)$.
} 
или правилата и стандардите за облекување на одредени работни позиции. Во првиот расказ, „Девојката од главниот град“ („La capitalina“), Мичелина Лаборде е принудена да носи тесни „blue jeans“ коишто ги откриваат облините на нејзиното тело, иако таа мечтае да носи здолниште со кринолин, зашто така ќе се чувствува слободна во своето тело, скриено од туѓите погледи. И во вториот расказ младиот студент по медицина, Хуан Самора, е принуден да носи џинс, бејзбол капче и тренерка со натпис од неговиот универзитет, зашто само така ќе може да мимикриски да се камуфлира “ во новата средина. Униформите, како лекарските мантили или униформите што треба да ги носат работничките во текстилните фабрики, честопати не служат само за да ги избришат индивидуалните обележја, па дури и половите разлики: „белата униформа (кога под неа не се гледаа влакнестите нозе), ја нагласуваше генерациската андрогинија“ (Fuentes 2016: 44, преводот е на авторката) $)^{6}$ туку и да ги истакнат класните разлики, да ги зацврстат хиерархиите: „ги кршеше правилата, што се замислуваше таа, облечена на работа како некоја светица, не знае ли дека треба да ја носи сината униформа, од безбедносни и хигиенски причини?““ (ibid, 131). Во посочениот случај со работничките во текстилната фабрика, надзорничката насилно ја соблекува „непослушната“" работничка, за да провери дали можеби работничката ја носи униформата под својата облека. Сличен пример на соголување на телото со цел негово понижување, а со тоа и зацврстување на одредена позиција на моќ, среќаваме и во првото поглавје каде што се зборува за тоа како жената на Леонардо Баросо и нејзините пријателки се забавуваат во слободното време. Имено, во домот на госпоѓата Баросо тие го принудуваат келнерот од домородно потекло да се разголува и да дефилира пред нив со послужавникот над главата. Ако во првиот случај на таканаречено класно насилство, пријателките застануваат во одбрана на својата колешка и се спротивставуваат на репресијата врз нејзиното тело, во случајот со насилство врз телото на расна основа, тоа останува само во рамките на гротескната, циркуска интимност на куќата на Леонардо Баросо, без можност да ги премине нејзините граници и да стане видливо. Иронично, она што е видливо - лифтинзите и хируршките зафати на кои се подвргнуваат богатите жени како госпоѓата Баросо-тие не го доживуваат како агресија врз нивните телото, бидејќи идеолошката позадина во ваквата создадена претстава за телото успешно се затскрива и слепо повикува на послушност (Симова 2012: 135).

Дека телата се обезвреднуваат, особено ако станат потчинети тела, зборува и описот на Мичелина Лаборде во првиот, а потоа и во седмиот расказ. Во првиот расказ таа е млада, привлечна девојка, потполно свесна за својата заводливост што умее да ја користи во своја полза и во овој расказ е опишана на следниов начин: „[...] совршена симетрија на издолжените црни очи, заштитени од луњавите клепки и нежната бура на подочниците: симетрија на

${ }^{6}$ Преводот на сите понатамошни цитати во оваа статија се на авторката. 
правиот нос, неподвижен, ако се изземат енергичните движења на ноздрите, немирни и вознемирувачки [...], (ibid, 14).

Во седмиот расказ, веќе во придружба на моќникот Леонардо Баросо, нема ни трага од младешкиот и енергичен изглед на Мичелина, сведена само на „луњавите клепки и нежната бура на подочниците“ (ibid, 173), коишто, симптоматично, повеќе ја немаат својата зашӣийичка функција.

И на лексички план може да се воочи одредена тенденција да се прикаже заробеноста на телата и изнудувачкиот однос кон нив. Тоа го забележуваме, на пример, во изборот на одредени глаголи во врска со конкретни делови од телото што укажуваат на присила и наметнување на нечија волја: „, rrancó $^{7}$

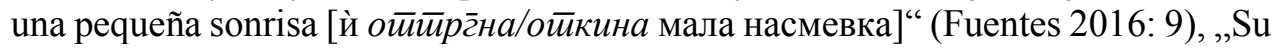

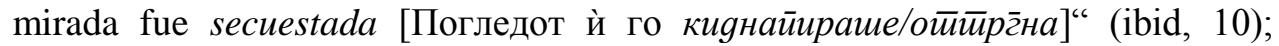
„,sonrisa fabricada en serie [сериски произведена насмевка]“ (ibid, 143); „Miss Amy trató de penetrar con su inteligencia los ojos negros, las carnes oscuras, las sonrisas anchas de los amigos de su criada, los mexicanos. [Госпоѓата Ејми се обиде да йpogpe со својата интелигенција во црните очи, темната кожа, широките насмевки на мексиканските пријатели на слугинката]“ (ibid, 167). Исто така, во неколку наврати се среќаваат и глаголи или партиципи со префикси што повторно означуваат некаква присила (а-), негација или лишување (in-, des-) или затворање во нешто (en-): ,ajuareadas del otro lado de la frontera, enjoyadas, casi todas con las cabelleras teñidas de caoba“ (ibid, 20); „las tangas que se les encajaban entre las nalgas“ (ibid, 142); „muslos, enfundados en unos jeans“ (ibid, 35); „con anteojos incrustado de diamantes“ (ibid, 21,); „,estaban enmascarados“ (ibid, 46); ,se tocaron las manos enguantadas“ (ibid, 46); „Me despojaron de mi corazón.“ (ibid, 105). ${ }^{8}$

Потчинетите тела во повеќе наврати ќе сакаат да се ослободат од репресијата и тоа ќе се манифестира токму преку желбата ослободувањето да се почувствува преку телото или преку одредени делови од телото. Веќе ја спомнавме Мичелина Лаборде којашто сака да носи здолниште од кринолин наместо фармерки за да може ги прекрстува нозете без никој тоа да го забележи или да не носи долна облека за да може да го чувствува „свежиот и слобоgен воздух“ на задникот (Fuentes 2016: 10, нагласок додаден од авторката) и за да ја буди фантазијата кај мажите коишто ќе мора да ја замислуваат. Маријано, синот на Леонардо, што ке биде принуден да склучи брак од интерес со Мичелина, сонува да биде оставен на мира со своите

\footnotetext{
7 Накосените зборови означуваат нагласок од авторката.

${ }^{8}$ Овие нијанси при преводот веројатно би се изгубиле. Овде ќе го понудиме значењето на глаголите што се истакнати со закосени букви со цел да дадеме барем приближна слика за она што го наведовме. Ajuarado, партицип од гл. ajuarear или ajuarar (се стекнува, добива мираз). Enjoyadas, партицип од гл. enjoyar (да се накити, да си стави накит). Encajaban, од гл. encajar (влегува, собира некаде). Enfundadas-од гл. enfundar (да стави во некаква навлака, футрола). Incrustado од incrustar (вметне, стави на некаква површина). Enmascarado, од гл. enmascarar (да стави маска). Enguantadas - од гл. enguantar (да покриеш раце со ракавици). Despojaron, од гл. despojar (лишува).
} 
книги, да живее во својот свет, речиси бестелесен како Исус: „Колку сакаше да ја остави зад себе бедата на минливото тело!“ (ibid, 28). Во овие два наведени случаи, односно телото преточено во имагинација, како еден вид бестелесна Дулсинеја, или телото што сака да достигне некаква возвишеност преку вонтелесното, добиваат позитивни конотации бидејќи произлегуваат од самите ликови, односно не се наметнати. Во други примери, бестелесноста или обезличувањето на телото најчесто ќе бидат наложени од други ликови или од одредени околности. На пример, во шестото поглавје, иронично насловено како „Пријателки“, на госпоѓата Ејми ѝ се чини дека нејзината слугинка Хосефина се движи низ станот како gyx, односно квалитетите на тивката и вредна Мексиканка, не само што не наидуваат на одобрување и пофалба кај нејзината господарка, туку метафорично таа е лишена и од својата телесност, од својата онтолошка димензија. Готвачот Дионисио од третиот расказ, пред да реши да го напушти САД, налетува на еден свој сограѓанин во излогот на една продавница, во онаа стереотипна положба на задреман Мексиканец со сомбреро на главата, за кого Дионисио има впечаток (затоа што и намерата е таква) дека се работи за кукла, што е очигледен случај на негација на телото преку негово опредметување. Емилијано Баросо од четвртиот расказ седи нейоgвижен, во йоиийолна ииемница и се сеќава на своето минато. Хуан Самора ја раскажува својата приказна сврииен со гррб, од срам кон сето она низ што поминал. Во овие примери или се атакува директно на идиосинкратската подвижност на телата или се инсистира на негово обезличување преку негирање на основниот и најпрепознатлив фрагмент од него-лицето. ${ }^{9}$

Понекогаш обезличувањето се случува поради неможноста индивидуата да се издвои од одредена безлична толпа: „Й одолеваше на толпата којашто секое утро ја впиваше додека одеше на работа, правејќи да се чувствува дел од стадото, индивидуално безначајна, неважна [...]“ (ibid, 188-89).

Иако, интересно е да се забележи дека кога ваквото обезличување се однесува на Мексиканците, а не на ликовите што се од северноамериканско потекло, тоа добива позитивни конотации, бидејќи ја претставува потребата да припаѓаат кон некое колективно тело, макар тоа било една безвредна, аморфна маса:

Доволно беше да се почувствува студенилото на излегување од терминалот и при влегување во автобусот за да биде благодарен за привремената јакна, за случајно добиениот шал, за топлината на другите тела. Се бараа и идентификуваа меѓу себе, можеше да се забележи како трагаа за да го најдат

\footnotetext{
9 Драшко Костовски (2004: 48) во трудот „Телото како текст од цитати“ вели дека „Главата секогаш имала предност над телото, главата-лицето е она што нѐ претставува, слика во лична карта, слика во некролог. Контактот се остварува преку очите, какво и да е телото, душата се претставува преку главата“. Лицето на Хуан Самора ќе се „разоткрие“ дури на крајот на расказот, кога тој ќе „се сврти“ кон нараторот ("Nos ha dado la cara” (Fuentes 2016: 60)) односно откако неговата приказна ќе биде раскажана, а со тоа и ќе му припадне на друг.
} 
пријателот што личи на нив, мисли како нив, дели заедничка територија со нив. (ibid, 182-83)

Во некои раскази, слободата на телата е само привид, бидејќи нивната субверзивност е минлива или немоќна да смени нешто. Во петтиот расказ, една од работничките ги соблекува чевлите со потпетици, кои во текстот во повеќе наврати се опишани како високи потпетици, како потпетици со остар врв, или како нож. Маријана, едната од работничките, ги соблекува чевлите за да оди боса по тревникот во округот на фабриката и покрај двојазичната табла за забрането газење по тревата и свесноста дека е набљудувана од газдите преку затемнетите прозорци на нивните канцеларии, како во некаков вид паноптикум. Чинот на тоа своевидно ослободување на телото е опишан како чудесен, речиси нереален:

[...] толку беше свежа, толку мокра и добро искосена тревата што ја скокоткаше на табаните и додека трчаше по неа, правеше да се чувствува како да се бања во некоја од оние маѓепсани шуми од филмовите [...] босите нозе, слободата на телото, слободата на она другото, како и да се вика, душата, како што се велеше во песните, слободно тело, слободна душа (ibid, 140).

При крајот на расказот, Маријана повторно ги соблекува чевлите со високи потпетици, но сега од умор, а не од бунтовност, пркос или желба за слобода. Помиреноста дека никогаш нема да го види морето, дека момчето со кое излегува е обичен измамник, дека нејзината судбина е текстилната фабрика, се чувствува и во овој симболичен чин на ослободување на телото, којшто во овој случај е биолошки детерминиран-поради чувството на болка и замор на телото-а не свесен, дискурзивен чин на субверзија како на тревникот во фабриката. ${ }^{10}$

Уште еден аспект поврзан со телесноста е телото во контакт со другите тела, односно границите на телесното и телото како единствено прибежиште во самотијата. Во вториот расказ за мексиканскиот студент по медицина во САД, референците за невидливите граници помеѓу телата може да се насетат во некои пасуси што ни ја навестуваат разделбата на телата, како на пример, во следнава реченица што се однесува на првата љубовна средба меѓу Хуан Самора и Џим: „Си ги допреа рацете преку ракавиците, со истото чувство како преку презерватив“" (ibid, 46). Но, исто така, и во некои поексплицитни ситуации на демаркација на просторот со другоста и со различноста, како на пример во делот каде што се вели дека мажот и жената од американското семејство, каде што е сместен Хуан Самора, откако ќе дознаат дека нивниот мексикански потстанар е хомосексуалец, нема да дозволуваат ќерката да биде

\footnotetext{
10 Човекот е „суштество на слободата и единственото кое го познава, организира, па дури и прифаќа -ропството“ вели Ферид Мухиќ (1994: 85) во цитираниот труд, а во посочената епизода можеме да го протолкуваме како обид за „замолчување“ на слободата и враќањ кон „ропството“, кон сериски произведената „среќа” во фабриката.
} 
во иста просторија со него. Иако агресијата врз телото не е директна или насочена кон конкретен дел од телот, како во некои од погоренаведените случаи, сепак го засега телото, овој пат во целиот негов тоталитет. Присуството на телото сега не само што го „имплицира“ просторот, како што велеше Туан, туку и го „електризира“, го претвора во полнеж од симболички значења што доаѓаат во судир со други идеолошки полнења, или, ако се претпочита, меѓучовечки празнења... Затоа, единствениот „спас“ за телото е неговото негирање преку отсуството. Хуан Самора ќе биде принуден да го напушти своето привременото прибежиште - домот на семејството Вингејт не само како жртва на лажниот американски морал и хипокризија туку и како жртва на потиснувањето на сопственото минато и идентитет.

Во третиот расказ за готвачот Дионисио, исто така е забележлива дистанцата помеѓу телата на Дионисио и жените со коишто тој вечера, не толку поради тоа што не се остварува намерата на Дионисио да спие со некоја од нив, туку повеќе затоа што се доведува под знак прашање и самата реалност на телата што тој, со сите детали, веројатно ги замислува пред него на масата ${ }^{11}$. Иако не се однесува конкретно на врската на Дионисио со некоја од овие жени, карактеристичен е описот на љубовниот живот на една од нив: „тројца мажи, три разводи, ниедно дете, повремени љубовници, сѐ подалечни, љубов преку телефон, оргазми на растојание, безбедна љубов, без проблеми, без телесни течности“ (ibid, 84). Повторно, како и во претходниот расказ, Дионисио си заминува од САД бидејќи стерилниот однос меѓу телата води до неизбежно отсуство на телата што само ја продлабочува неможноста за нивно запознавање, а со тоа и поголемо самоспознавање.

Најпарадигматичен расказ за дистанцата меѓу телата е несомнено осмиот расказ, „Стаклената граница“. Во овој расказ приказната ги става во фокусот двајца луѓе од различни земји, култури и општествени статуси чијшто контакт е возможен единствено преку стаклото на прозорецот од зградата каде што по некоја случајност се наоѓаат и двајцата. Контактот не може да биде целосен бидејќи иако го вклучува погледот и симултаноста на допирот на дланките од двете страни на стаклото, сепак не е физички и телесен. На некој начин, оваа епизода би можела да се сфати како еден вид продлабочување на значењето за хетеротропија што го дефинираше Фуко (Foucault 1984), бидејќи ако според Фуко огледалото е местото каде што се гледам себеси, но од каде што истовремено сум и отсутен, прозорецот како стаклена граница станува еден вид превртено огледало, што го потврдува отсуството на другата страна, но дава и една искривена слика за јаството од оваа страна. Имено, кон крајот на расказот, момчето и девојката, чувствуваат потреба да ја овенчаат оваа нивна несудена средба споделувајќи си ги барем имињата. Девојката го пишува своето име Audrey, но од другата страна тоа се

\footnotetext{
${ }^{11}$ Во ова поглавје, би можеле да му забележиме на авторот за одредена фалогоцентрична слика на мажот, поистоветен со умот, со мислечкиот процес, а жената со стриктно телесното, кое се замислува и отелотворува само во фантазијата на мажот.
} 
чита наопаку, Yerdua, по што следи коментар на нараторот дека вака напишаното име потсетува на некакво егзотично име на индијанска божица. А момчето, воопшто не го ни пишува своето сопствено име, туку ѝ одговара со својата националност: „nacixem“, односно mexicano, Мексиканец. Дистанцата меѓу телата, иако е минорна, премостлива, проsирна и банална, е тука за да ја потврди нивната „неприкосновена самотија“ (Fuentes 2016: 196), самотијата како прибежиште, како „комфорт-зона“ во која нема место за другоста.

Посебно внимание заслужува односот меѓу телото и смртта. Преку смртта, на некој начин се обединуваат речиси сите досега спомнати односи кон телото: слободата, обезличеноста, статичноста, омеѓеноста. Во вториот расказ, кој беше предмет на анализа во неколку наврати, Хуан Самора и Џим се запознаваат во моментот кога се во мртовечница и треба да прават дисекција на труп. Во овој случај немаме само повторно разобличување на телото за кое тие не можат да одредат дали му припаѓa на маж или на жена бидејќи „,[с]мртта ја лишува индивидуата од заменки“ (ibid, 46), туку и суптилно потчинување на телото коешто станува инструмент за истражување, односно „корисно, наменско“ тело како што вели Браидоти (2002: 92). Ако повторно се повикаме на Браидоти, дека „само мртвото тело може да ја открие мистеријата на животот“ (ibid, 91), тогаш интересен е заклучокот што произлегува од овој расказ, односно дека двајцата млади идни доктори го дисецираат туѓото, безимено тело во името на спознанието, но ова спознание не води и до нивно меѓусебно спознание.

Смртта е присутна преку неколку посредни алузии, како на пример описот на лицето на Мичелина Лаборде кое наликува на „совршен череп“ (Fuentes 2016: 14), преку ониричната антропофагија на Дионисио, којшто не знае дали јаде со жените, ги јаде или тоа еден вид заедничка кулинарска жртва (ibid, 81), или експлицитно преку информациите за мртвото дете на една од работничките во фабриката, ${ }^{12}$ преку самоубиството на Леандро и Енкарнасион како единствен начин да ја надминат својата самотија и да го остварат негираното заедништво. Сепак, би рекле дека централен расказ за

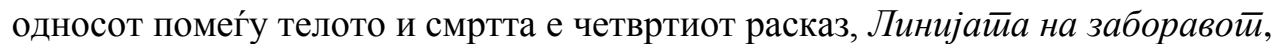
каде што, иако не е сосема извесно дали протагонистот умира (се алудира само на тоа дека повеќе никогаш нема да може да го изговори сопственото име), во овој расказ е особено тесна врската помеѓу инертноста на телото како асоцијација за смртта, и желбата телото да се почувствува во секој нејзин детаљ, како потврда за животот. Без точно да се прецизираат просторните и

\footnotetext{
12 Оваа епизода со смртта на ликот Динора, којашто е единствената што го издржува семејството благодарение на работата во фабриката, може да се протолкува и како неможност жената, односно женското „потенцијално [а во случајов и реализирано] мајчинско тело“ (Грос 2003: 46) да постигне родова рамноправност. Смртта на детето кое било врзано за масата за да не побегне додека мајката е на работа, е казната што индиректно ѝ ја наметнува патријархалниот систем на жената што ќе го напушти домот и ќе се обиде да го оствари правото на своето присуство, својата телесност во јавната сфера.
} 
временските координати во кои се наоѓа ликот, единственото нешто што со сигурност се знае за Емилијано Баросо е дека се наоѓa во инвалидска количка и дека пред себе гледа една светла трага од непознато потекло, што се рефлектира крај неговите нозе и што тој ја нарекува граница. Алузијата на границата меѓу САД и Мексико е повторно присутна, иако во овој расказ повеќе станува збор за една временска граница меѓу сегашноста и потиснатите спомени, меѓу јаството и другите, како иманентен дел на тоа јас. Односно, расказот претставува еден вид нурнување во личното минато на протагонистот кое ќе треба да доведе до повторното враќање на идентитетот, но тоа сознание, како и во делото Педро Парамо на сонародникот на Фуентес, неизбежно води до смрт. Она што е впечатливо во тој чин на повторно себеспознавање е токму тоа што тој неминовно води преку телото, односно нараторот постојано инсистира, „осветлувајќи“ дел по дел од телото, ликот да се отелотвори, да се изнедри од темницата на заборавот, а тоа се забележува во мошне долгата листа на деловите од телото што се спомнуваат во овој расказ: лице, тил, прсти, колена, стапала, скут, глужд, нос, дланки, раце, мочен меур, полов орган, очи, чело, јазик, влакна, нокти, задник, вилица. Некогаш авторот се служи со куси, елиптични реченици: „Моето лице. Мојот тил“ (Fuentes 2016: 95) или набројувања преку кои повторно се инсистира на тоа телото јазично да се „опипува“ за нѐ се изгуби од вид неговото физичко присуство. Впрочем, и самиот избор на нараторот во прво лице, на употребата на сегашното време во текстот, на постојаното нагласување на неподвижноста на телото што е во спротивност со збиеноста на лаконските реченици, се дел од техниките употребени во овој расказ за тој да може да кулминира со уште суштинското „Тоа сум јас“ (ibid, 119). Иронично, колку повеќе телото добива на форма и се стреми кон целосност, толку поблиску е до границата на смртта и толку повеќе се разобличува заблудата за некакво можно тотализирачко самоспознавање.

Остануваат уште дузина спреги во текстот што не успеавме да ги опфатиме во овој труд, но се надеваме дека преку понудената анализа на делото на Фуентес низ призмата на телесното покажавме дека телото е еден сложен концепт што секогаш треба да се разгледува во релација со географските, општествените и културните детерминанти, и дека слично како и границите, и телото наликува на двоглавиот бог Јанус, со едното лице свртено кон себе, а другото кон другите, кон сегашноста и кон минатото, кон индивидуалното и колективното, без да може да се каже кое од овие две лица е доминантно, вистинско или валидно. „Стаклената граница“ е само навидум едно дело за помирување на двата света „толку далеку од бога, толку блиски еден до друг“ (ibid, 273), за што потврда наоѓaме како во инсистирањето на секаков вид алузии на границата (линии, лузни, пречки, меѓи) или на непремостливите разлики меѓу двете земји, така и во загубената присност и отуѓeноста на телата од себе и од другите, за кои стана збор во овој труд. 


\section{Библиографија}

Anzaldúa, G. (1987). The Borderlands/La frontera: The New Mestiza. San Francisco: Aunt Lute Books.

Augé, M. (1992). Los «no lugares». Espacios del anonimato. Una antropología de la sobremodernidad. Barcelona: Gedisa.

Boldy, S. (2000). Lo real fronterizo en La frontera de cristal de Carlos Fuentes. América: Cahiers du CRICCAL, 25: 83-3. Пристапено на 26.02.2017: http://www.persee.fr/doc/ameri_0982-9237_2000_num_25_1_1478

Fuentes, C. (2016). La frontera de cristal. Barcelona: Debolsillo.

Foucault, M. (1984). De los espacios otros. Преземено од: http://yoochel.org/wp-content/uploads/2011/03/foucalt_de-los-espacios-otros.pdf

Foucault, M. (1998). Historia de la sexualidad 1. Madrid: Siglo XXI.

Tuan, YF. (1979). Space and Place: Humanistic Perspective. Gale S., Olsson G. (eds.) Philosophy in Geography. Theory and Decision Library, Vol 20: 387-27. Springer: Dordrecht. Пристапено на: 02.09.2017: http://geog.uoregon.edu/amarcus/geog620/Readings/Tuan_1979_space-place.pdf

Paredes Ortiz, J. Desde la corporeidad a la cultura. Revista Digital, 62. Пристапено на: 10.02.2018: http://www.efdeportes.com/efd62/corpo.htm

Браидоти, Р. (2002). Номаgски субјектии: ойелойворување и сексуална разлика во современайа феминисиичка йеорија. Скопје: Македонска книга.

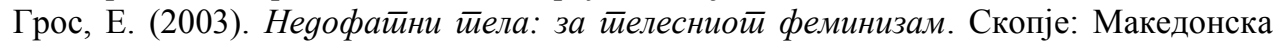
книга.

Костовски, Д. (2004). Телото како текст од цитати, Кулииурен живой, 43/3: 46-53.

Мухиќ, Ф. (1994). Ноуменолог̄ија на йелойо. Скопје: Табернакул.

Симова, А. (2012). Дискурсот на телото и телото како дискурс: медиумските претстави за телесноста. Сиеекӣар: сйисание за литерайурна наука, бр. 59: 13042.

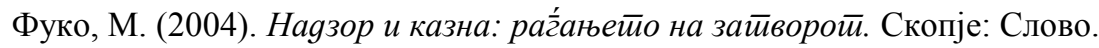

